\title{
Bibliometric analysis of research on the role of intestinal microbiota in obesity
}

\author{
Haiqiang Yao ${ }^{\text {Corresp., }}{ }^{1,2,3}$, Jin-Yi Wan ${ }^{1,2,3}$ ， Chong-Zhi Wang ${ }^{2,3}$ ， Lingru Li ${ }^{1}$, Ji Wang ${ }^{1}$, Yingshuai Li ${ }^{1}$, Wei-Hua \\ Huang ${ }^{2,3}$, Jinxiang Zeng ${ }^{2,3}$, Qi Wang ${ }^{1}$, Chun-Su Yuan ${ }^{2,3,4}$ \\ 1 Beijing University of Chinese Medicine, Beijing, China \\ 2 Tang Center for Herbal Medicine Research, The University of Chicago, Chicago, IL, United States \\ 3 Department of Anesthesia and Critical Care, The University of Chicago, Chicago, IL, United States \\ 4 Comprehensive Cancer Center, The University of Chicago, Chicago, IL, United States \\ Corresponding Author: Haiqiang Yao \\ Email address: hqyao@uchicago.edu
}

Background: Obesity is a key public health problem. The advancement of gut microbiota research shed new lights on this field. This article aims to present the research trends in global intestinal microbiota studies within the domain of obesity research. Methods: Bibliographic information of the publications on intestinal microbiota and obesity was retrieved from Scopus database, and then analyzed by bibliometric approaches. Results: A total of 3446 references were retrieved, the data indicated a steady growth and an exponential increase in publication numbers. The references were written in 23 different languages (93.8\% in English). A number of 3056 English journal papers were included in the further analyses. Among the 940 journals, the most prolific ones were PLoS One, Scientific Reports, and British Journal of Nutrition. North America and Europe were the highest publication output areas. The US (995 publications) ranked first in the number of publications, followed by the China (243 publications) and France (242 publications). The publication numbers were significantly correlated with gross domestic product (GDP), human development index (HDI), and population number (PN). International collaboration analysis also shows that most of the collaborations are among developed countries. Discussion: This comprehensive bibliometric study indicates that gut microbiota is a significant topic in the obesity research. The structured information may be helpful in understanding research trends, and locating research hot spots and gaps in this domain. 


\section{Bibliometric analysis of research on the role of intestinal microbiota \\ in obesity}

Haiqiang Yao $\dagger^{1,2,3}$, Jin-Yi Wan $\dagger^{1,2,3}$, Chong-Zhi Wang ${ }^{2,3}$, Lingru Li ${ }^{1}$, Ji Wang ${ }^{1}$, Yingshuai Li $^{1}$, Wei-Hua Huang ${ }^{2,3}$, Jinxiang Zeng ${ }^{2,3}$, Qi Wang ${ }^{1 *}$, Chun-Su Yuan ${ }^{2,3,4}$

${ }^{1}$ Beijing University of Chinese Medicine, Beijing 100029, China;

2 Tang Center for Herbal Medicine Research, The University of Chicago, Chicago, IL 60637, USA

3 Department of Anesthesia and Critical Care, The University of Chicago, Chicago, IL 60637, USA

${ }^{4}$ Comprehensive Cancer Center, The University of Chicago, Chicago, IL 60637, USA

\section{*Corresponding Author}

2 Qi Wang, E-mail: wangqi710@126.com. Tel/Fax:+86-10-64286312. 


\section{Abstract}

25

26

3
research shed new lights on this field. This article aims to present the research trends in global intestinal microbiota studies within the domain of obesity research. Methods: Bibliographic information of the publications on intestinal microbiota and obesity was retrieved from Scopus database, and then analyzed by bibliometric approaches. Results: A total of 3446 references were retrieved, the data indicated a steady growth and an exponential increase in publication numbers. The references were written in 23 different languages (93.8\% in English). A number of 3056 English journal papers were included in the further analyses. Among the 940 journals, the most prolific ones were PLoS One, Scientific Reports, and British Journal of Nutrition. North America and Europe were the highest publication output areas. The US (995 publications) ranked first in the number of publications, followed by the China (243 publications) and France (242 publications). The publication numbers were significantly correlated with gross domestic product (GDP), human development index (HDI), and population number (PN). International collaboration analysis also shows that most of the collaborations are among developed countries. Discussion: This comprehensive bibliometric study indicates that gut microbiota is a significant topic in the obesity research. The structured information may be helpful in understanding research trends, and locating research hot spots and gaps in this domain.

4

5

46

47

8

9


54

55

56

57 58

\section{Introduction}

Obesity, marked by the excess body fat accumulation, is a major public health crisis. This medical condition has almost become a global epidemic and is progressing rapidly (Barbieri et al. 2017; D'Souza et al. 2017). Among factors, intestinal microbiota can influence the whole-body metabolism by affecting the host's energy homeostasis(de Vadder \& Mithieux 2018; OmariSiaw et al. 2016). There are ample studies showing that probiotics and prebiotics, or other dietary substances, can be used to alleviate obesity through the modulation of the host's intestinal microbiota (Bird et al. 2017; Li et al. 2017a; Li et al. 2017b). However, to date, the role of intestinal microbiota in the formation and progression of obesity has not been systematically presented using bibliometric analysis.

Bibliometric analysis can be applied to track the developing trends, access the influences of publications, and compare the academic performance between different regions of a certain research field. This bibliometric technique has been applied in the domain of obesity; one publication investigated studies from 1998 2007 using data from PubMed (Vioque et al. 2010), and another study analyzed the longitudinal trends from 1993 to 2012 with Scopus as the data source (Khan et al. 2016). However, to our knowledge, thus far, no bibliometric studies have assessed intestinal microbiota and obesity research at the global level.

The aim of this study was to present an overview of the research trends on intestinal microbiota and obesity up to now and shed new light on future research directions. We investigated the growth and citation of publications, active authors, countries and institutions, international collaboration, and the frequency of terms through a bibliometric analysis.

\section{Methods}

\section{Search strategy}

7 Bibliometric data can be acquired through various search engines. In this study, Scopus database was selected to perform the literature search for all published articles on enteric microbiota and obesity. It was justifiable to use Scopus as our data source to retrieve abstracts, citations and other bibliometric data given that it has wider resources and is consistently more accurate than other alternatives such as PubMed, Web of Science and Google Scholar (Choudhri et al. 2015; Falagas et al. 2008; Kulkarni et al. 2009). 
83

84 85 86 87 88 89

The Scopus database was searched from its inception to May 30, 2017 with no language limitation. The synonyms for gut microbiota and obesity were included in the search strategy. The keywords pertaining to gut microbiota were: gastrointestinal microbiomes, gut microflora, gut microbiota, gastrointestinal flora, gut flora, gastrointestinal microbiota, gut microbiome, gastrointestinal microflora, intestinal microbiome, intestinal microbiota, intestinal microflora, and intestinal flora. The keywords regarding obesity were: obesity, corpulence, fatness, and overweight. The two sets of keywords were searched with the AND logic in the Article title/ Abstract/ Keywords fields. The final search query was built like this:

( ( TITLE-ABS-KEY ( gastrointestinal AND microbiomes ) OR TITLE-ABS-KEY ( gut AND microflora ) OR TITLE-ABS-KEY ( gut AND microbiota ) OR TITLE-ABS-KEY ( gastrointestinal AND flora) OR TITLE-ABS-KEY ( gut AND flora ) OR TITLE-ABS-KEY ( gastrointestinal AND microbiota ) OR TITLE-ABS-KEY ( gut AND microbiome ) OR TITLE-ABS-KEY ( gastrointestinal AND microflora ) OR TITLE-ABS-KEY ( intestinal AND microbiome ) OR TITLE-ABS-KEY ( intestinal AND microbiota ) OR TITLE-ABSKEY ( intestinal AND microflora ) OR TITLE-ABS-KEY ( intestinal AND flora ) ) AND PUBYEAR < 2018 ) AND ( ( TITLE-ABS-KEY ( obesity) OR TITLE-ABS-KEY ( corpulence ) OR TITLE-ABS-KEY ( fatness ) OR TITLE-ABS-KEY ( overweight ) ) AND PUBYEAR < 2018 ).

All of the citation information, bibliographical information, abstract and keywords, funding details and other information of the retrieved publications was exported with CSV format through the University of Chicago Library's access, for the further data processing.

\section{Data analysis}

All bibliometric information was exported into CSV format from the Scopus database. Microsoft Excel was applied to for sorting and to perform statistical procedures. Top prolific authors, countries, journals, institutions and most cited papers were ranked according to the standard competition ranking (SCR). Data visualization was conducted using the VOSviewer technique to create scientific landscapes and networks based on the citation frequency, countries, journals, authors and other information (van Eck \& Waltman 2010). GunnMap 2 (http://lert.co.nz/map/) was used to generate the world map to show the publication distribution.

Some bibliometric indicators were applied in the analysis. The strength of publications 
113 included was assessed by impact factor (IF) obtained from the latest Journal Citation Report

114 (2016) published by Thomson Reuters. Bradford's Law was used as a scattering index to reveal

115 the distribution of the scientific literature in a particular discipline. Bradford proposed a model of

116 concentric zones of productivity, termed as Bradford zones, with decreasing densities of

117 literature. Each of these zones would contain a similar number of articles, but the number of

118 journals in which these articles are published would increase on passing from one zone to

119 another (SC 1948). This model permits the identification of journals that are most widely used or

120 have the greatest weightage in a given field of scientific production.

121 GraphPad Prism version 6.0c (San Diego, CA, USA) was used to conduct statistical

122 analysis. Pearson's correlation analysis was used to investigate relationships between the

123 publication numbers of different countries/regions and some related variables, such as gross

124 domestic product (GDP), GDP per capita (purchasing power parity, PPP), etc. A $P$ value of $<$

1250.05 was considered statistically significant.

\section{Results}

127

128

130

131

132

133

134

135

136

137

138

139

140

141

\section{Publications analysis based on numbers and citations}

The applied strategy yielded a total of 3446 publications. The first article on gut microbiota and obesity was published in 1968, and the annual publication numbers were stable in the following nearly 40 years till 2004. A dramatic growth was observed in the last 15 years from 2003 to 2017, and the number of annual documents during this period showed an exponential growth trend $\left(\mathrm{y}=0 \mathrm{e}^{0.4263 \mathrm{x}}, \mathrm{R}^{2}=0.94\right)$. The specific numbers of annual documents and accumulated documents are shown in Fig. 1A. The highest number of annual publications was seen in 2017, totaling 702 publications. The publication numbers of obesity research (Fig. 1B) can serve as a background frame to present a better understanding of the growth trend of intestinal microbiota in obesity research. As shown in Fig. 1C, the percentage of intestinal microbiota related publications in the obesity research was increasing gradually, especially after the year of 2006 .

In terms of document type, the majority of the retrieved papers were research articles $(\mathrm{n}=$ $1826,53.0 \%)$, followed by review articles $(\mathrm{n}=1110,32.2 \%)$ and book chapters $(\mathrm{n}=103,3.0 \%)$ (Fig. 2A). The primary source of the publications was journals (Fig. 2B). As shown in Fig. 2C, 
142 most of the retrieved documents belong to medical subjects ( $n=2324,67.4 \%)$, followed by 143 Biochemistry, Genetics and Molecular Biology $(\mathrm{n}=1106,32.1 \%)$, Nursing ( $\mathrm{n}=554,16.1 \%)$,

144 Immunology and Microbiology ( $\mathrm{n}=466,13.5 \%)$, and Agricultural and Biological Sciences $145(n=459,13.3 \%)$. The retrieved papers were written in 23 different languages, mainly in English $146(n=3232,93.8 \%)$, followed by French $(n=65,1.9 \%)$, Chinese $(n=37,1.1 \%)$, German $(n=33$, 147 1.0\%), and Spanish ( $\mathrm{n}=24,0.7 \%)$.

148 All of the retrieved 3446 papers were cited a total of 141918 times. A total of $2858(82.9 \%)$ 149 articles had at least one citation while 588 (17.1\%) articles had no citations.

150 Among the total 3446 documents there were multiple source types (Fig. 2B) that were 151 written in different languages (Fig. 2D). Considering the heterogeneity of the documents may 152 add background noises to the study, we only included the journal articles written in English to 153 perform the further analyses. According to this inclusion criteria, a total of 390 documents 154 (books, book series, conference proceedings and other types) were excluded. 3056 English 155 papers were included for the subsequent analyses.

\section{Publications analysis based on top cited articles}

157 Top 20 cited papers are listed in Table 1 (Bäckhed et al. 2004; Bäckhed et al. 2005; 158 Bäckhed et al. 2007; Cani et al. 2007; Cani et al. 2008; Cani et al. 2009; Henao-Mejia et al. 2012; 159 Kau et al. 2011; Le Chatelier et al. 2013; Ley et al. 2005; Ley et al. 2006; O'Hara \& Shanahan 160 2006; Qin et al. 2010; Ridaura et al. 2013; Tremaroli \& Bäckhed 2012; Turnbaugh et al. 2008; 161 Turnbaugh et al. 2009a; Turnbaugh et al. 2006; Turnbaugh et al. 2009b; Vijay-Kumar et al. 162 2010). The highest citation number was 3961 for the article entitled "An obesity-associated gut 163 microbiome with increased capacity for energy harvest” (Turnbaugh et al. 2006). Among the top 16420 highly cited papers eight were published in Nature, followed by Science and Proceedings of the National Academy of Sciences of the United States of America (three papers), Diabetes (two 166 papers). As the first author, Turnbaugh P.J. published four papers among the top 20 cited papers, 167 followed by Bäckhed F. and Cani P.D. (three papers), then by Ley R.E. (two papers). Among the 168 top 20 cited papers, Gordon, J.I. participated 12 papers, followed by Ley R.E. (six papers) and 169 Bäckhed F. (five papers), they were the most productive of the highest quality authors. 
170

171

172

173

174

175

176

177

178

179

180

181

182

183

184

185

186

187

188

189

190

191

192

193

194

195

196

198

199

197 In order to achieve a better understanding of the diverse publication numbers in different

\section{Publications analysis based on authors}

A total of 10648 authors contributed to the publication of all the 3056 papers included. The number of authors for a single document, also known as the transience index, is 8224, accounting for $77.2 \%$ of all the authors. There are 85 authors who published more than ten articles in this field. Cani, P.D. was the most productive author in this field with 76 publications, the following were Delzenne, N.M. (52 publications) and Bäckhed, F. (48 publications). Details of the top 20 most prolific authors are presented in Fig. S1A, and the co-authorship analysis is shown in Fig. S2.

A total of 9590 authors have been cited at least once, accounting for $91.7 \%$ of the total 10462 authors, 6064 authors had citation numbers at least 10 (58.0\%), and 1597 authors have been cited at least 100 times (15.3\%). Gordon J.I. was the most influential author with the greatest citation number of 25073, followed by Ley R.E. (17658), and Bäckhed F. (15518); details of citation analysis are represented in Fig. 3. Among the top 20 most cited authors, Batoo, J.-M., Levenez, F. and Renault, P. had the greatest citation numbers per publication (1303.8), followed by Tap, J. (1297.5) and Parkhill, J. (1291.5), more details are shown in Fig. S1B.

\section{Publications analysis based on countries/regions}

The geographical distribution of publications involved 79 countries/regions over six continents (Fig. 4). There were 20 countries that just published only one article, and 46 countries that published at least 5 articles. The top 20 most productive countries are shown in Fig. S1C; the US ranked first with 995 publications, followed by China (243 publications), France (242 publications), United Kingdom (223 publications), and Italy (196 publications). However, the GDP-adjusted ranking according to their productivity scores was different, the most prolific countries were Finland, Denmark, Ireland, Belgium, and Swaziland (Fig. S1D). Publication productivity scores of countries/regions were calculated by dividing the number of publications by their GDP and then multiplying the result with by $1 \mathrm{E}+12$. As shown in the Fig.S1E, the most productive continents according to the publication numbers were Europe, North America, and Asia. countries/regions, the relationship between the publication numbers and multiple factors for each country was investigated. The analyzed factors were population number $(\mathrm{PN})$, gross domestic 
200 product (GDP), gross domestic product per capita (purchasing power parity, PPP), and human 201 development index (HDI). Significant correlation was found between the publication number of 202 intestinal microbiota in obesity research and GDP, HDI, and PN (Fig. 5). GDP demonstrated the 203 highest correlation with the publication number ( $\mathrm{r}=0.89, p<0.0001)$, followed by HDI ( $\mathrm{r}=0.32$, 204 $p<0.001)$ and PN $(\mathrm{r}=0.27, p<0.05)$. GDP was the most important factor that could benefit the publication productivity. Therefore, this analysis can interpret the reason why the US and China were the most prolific countries in this domain.

Analysis of citation counts for countries showed that the US had the most citations followed 208 by France, UK, Belgium and the Netherlands (Fig. S3). The international collaboration analysis based on these countries is shown in a network visualization map (Fig. S4). As is indicated in the collaboration analysis, the United States (US) had collaborations with other 38 countries and

211 followed by Italy (35 collaboration links), Spain (33 collaboration links), United Kingdom (UK)

212 (32 collaboration links), and Germany (31 collaboration links). For the US, collaboration was 213 mostly with China (relative link strength $=64$ ) and Canada (relative link strength $=45$ ).

\section{Publications analysis based on institutions}

215 Prolific institutions in publishing papers on gut microbiota and obesity are presented in 216 Table 2. The most active institution was University College Cork in Ireland (122 publications), 217 followed by The Institut national de la santé et de la recherche médicale (Inserm) in France (109 218 publications), and Universite Catholique de Louvain in Belgium (95 publications). A total of 160 219 institutions published at least 10 articles. Among the top 20 most active institutions, 14 are in 220 Europe, four and in North America, and two are in China. A total of 79 organizations have been 221 cited at least 1000 times, the citation analysis was shown in Fig. S5. The Department of 222 Chemistry and Biochemistry, University of Colorado obtained the highest citation number (7930 223 citations), and followed by Center for Genome Sciences, Washington University in St. Louis 224 (5032 citations) and Danone Research, in France (4652 citations).

\section{Publications analysis based on journals}

226

All the retrieved documents were published in 940 different journals. The top 20 active 227 journals in publishing articles on gut microbiota and obesity are shown in Table 3. The most 228 prolific journal in this field was PLoS One (106 publications), followed by Scientific Reports (46 
229 publications), and British Journal of Nutrition (43 publications). The total number of articles 230 published in top 20 journals was 728 , accounting for $23.8 \%$ of total retrieved documents.

231 Citations analysis of the included 143 journals with at least 5 publications indicated that Nature

232 has the highest citation numbers ( $\mathrm{N}=22139)$, followed by Proceedings of The National Academy 233 of Sciences of The United States of America (N=10195), and PloS One (N=5117) (Fig. 6).

234 Regarding the academic journals publishing articles on gut microbiota and obesity, the Bradford 235 model was applied. The division of Bradford's zones in this study is shown in Table 4. A total of 236940 journals were involved; the average number of articles in each zone was 305.6. The first 237 zone included six journals: Plos One, Scientific Reports, British Journal of Nutrition, Nutrients, 238 Gut Microbes, and Cell Metabolism.

239

240

241

242

243

244

245

246

247

248

249

250

251

252

253

254

255

256

257

\section{Publications analysis based on terms frequency}

A density visualization map of most frequently encountered terms is shown in Fig. 7. This analysis was performed based on the terms extracted from the title and abstract fields of retrieved publications; a number of 195 terms met the threshold with a minimum number of occurrences as 100 . The term with the highest frequency was obesity $(\mathrm{N}=4677)$, followed by gut microbiota $(\mathrm{N}=3437)$, and $\operatorname{diet}(\mathrm{N}=2267)$.

\section{Discussion}

Obesity is a leading cause of preventable death in the U.S. Obesity induces a number of health problems, both independently and in association with other diseases, such as coronary heart disease, type 2 diabetes, and an increased incidence of several forms of cancer (Feng et al. 2015; Ozturk 2017; Wang et al. 2015). Some variables such as host genetics, sedentary lifestyle and high-fat diet are identified as etiological factors of obesity (Cheng et al. 2016; Kobyliak et al. 2016), however, the in-depth pathogenesis that accounts for the development of obesity has yet to be disclosed.

Experimentally, model organisms provide an important approach for understanding the cause behind different disorders. Animal models approximate some human diseases, such as diabetes and obesity, and could reproduce many these medical conditions. As is indicated in recent enteric microbiota studies, the community of microorganisms residing in the gastrointestinal tract, is playing a major role in the onset and development of obesity (Duranti et 
258 al. 2017; Kvit \& Kharchenko 2017). The roles of microbiota can be explored within the 259 constraints of particular animal model systems, although standard models of inbred mice are 260 limited by their uncontrolled microbiome diversity (Cho \& Blaser 2012).

261 Intestinal microbiota is involved in the pathogenesis of obesity through various of pathways.

262 Gut microbiota can influence the whole-body metabolism by affecting the host's energy 263 homeostasis through the mechanism of adjusting the quantity of effector molecules to finally 264 regulate the fat storage in adipocytes (Bai et al. 2016; de Clercq et al. 2016). Besides, gut 265 saccharolytic microorganisms can degrade complex dietary glycans, which humans cannot 266 utilize directly, and then provide the host with a variety of metabolites. This process may exert extensive influence on the glucose, cholesterol, and lipid metabolism (Duranti et al. 2017).

Modern lifestyles that change the selection pressures on microbiomes could alter exposures to bacteria during the early lives of hosts and thus may contribute to the development of obesity. Antibiotic use in human infancy was significantly associated with obesity development (Ajslev et al. 2011). Alterations in the enteric microbiome also occur when interventions are used to treat obesity ( $\mathrm{Li}$ et al. 2011). Thus, modulation of the host's enteric microbiota is a promising way to reduce human obesity (Li et al. 2017b; Zhang et al. 274 2014).

275 Bibliometric study is based on the comprehensive analysis of publications' bibliographic 276 data, such as authors' affiliations, publication types, source countries, funding and citation 277 information (Pritchard 1969). In this study, the significance of intestinal microbiota in the 278 progression and management of obesity has been analyzed using a bibliometric approach. The 279 present study is the first time that a bibliometric overview of academic publications on the topic 280 of intestinal microbiota and obesity has been presented. The percentage of intestinal microbiota 281 related publications in the field of obesity research has been soaring in recent years.

282 North America and Europe are the most prolific areas in this field; the U.S. and China are

283 the top two most productive countries. Several factors are revealed to be significantly associated 284 with the publication numbers of this field. The most positively related factor is GDP, which can 
285 partly explain the highest productivity of the US. The HDI and PN also show a positive 286 correlation with the publication numbers, but are weaker than GDP.

287 The most productive journals in this field are PLoS One, Scientific Reports, and British 288 Journal of Nutrition. The most productive institutions are University College Cork in Ireland, 289 Inserm in France, and Universite Catholique de Louvain in Belgium. International collaboration 290 analysis also shows that most of the collaborations are between developed countries. However, a 291 multitude of developing countries are also suffering from the increasing prevalence of obesity 292 (Nasreddine et al. 2017), so this study reveals the necessity of developed countries to support the 293 developing regions in gut microbiota and obesity-related research in order to address this issue 294 on a global scale.

\section{Conclusions}

Intestinal microbiota is playing a significant role in the obesity research. Data obtained from this study represented the global research trends, collaboration patterns, and spatial density of the role of intestinal microbiota in obesity. These data are helpful for scientific researchers and public health policymakers in research planning and decision-making of this domain. The current study can also benefit scientists to locate research hot spots and gaps by offering comprehensive analyses and structured information on this topic.

\section{Acknowledgements}

The authors would like to thank the University of Chicago for giving us the opportunities to 305 access the most recent information sources such as Scopus database. Our thanks also go to Clara Sava-Segal from the University of Chicago for editing the manuscript.

\section{Abbreviations}

SCR: standard competition ranking; IF: impact factor. 
310

311

312

313

314

315

316

317

318

319

320

321

322

323

324

325

326

327

328

329

330

331

332

333

334

335

336

337

338

339

340

341

342

343

344

345

346

347

348

349

350

351

352

353

Ajslev TA, Andersen CS, Gamborg M, Sorensen TIA, and Jess T. 2011. Childhood overweight after establishment of the gut microbiota: the role of delivery mode, prepregnancy weight and early administration of antibiotics. International Journal of Obesity 35:522-529. 10.1038/ijo.2011.27

Bäckhed F, Ding H, Wang T, Hooper LV, Koh GY, Nagy A, Semenkovich CF, and Gordon JI. 2004. The gut microbiota as an environmental factor that regulates fat storage. Proceedings of the National Academy of Sciences of the United States of America 101:15718-15723.

Bäckhed F, Ley RE, Sonnenburg JL, Peterson DA, and Gordon JI. 2005. Hostbacterial mutualism in the human intestine. Science 307:1915-1920.

Bäckhed F, Manchester JK, Semenkovich CF, and Gordon JI. 2007. Mechanisms underlying the resistance to diet-induced obesity in germ-free mice. Proceedings of the National Academy of Sciences 104:979-984.

Bai J, Zhu Y, and Dong Y. 2016. Response of gut microbiota and inflammatory status to bitter melon (Momordica charantia L.) in high fat diet induced obese rats. $J$ Ethnopharmacol 194:717-726. 10.1016/j.jep.2016.10.043

Barbieri M, Desesquelles A, Egidi V, Demuru E, Frova L, Mesle F, and Pappagallo M. 2017. Obesity-related mortality in France, Italy, and the United States: a comparison using multiple cause-of-death analysis. International Journal of Public Health 62:623629. 10.1007/s00038-017-0978-1

Bird JK, Raederstorff D, Weber P, and Steinert RE. 2017. Cardiovascular and Antiobesity Effects of Resveratrol Mediated through the Gut Microbiota. Advances in Nutrition 8:839-849. 10.3945/an.117.016568

Cani PD, Amar J, Iglesias MA, Poggi M, Knauf C, Bastelica D, Neyrinck AM, Fava F, Tuohy KM, Chabo C, Waget A, Delmee E, Cousin B, Sulpice T, Chamontin B, Ferrieres J, Tanti JF, Gibson GR, Casteilla L, Delzenne NM, Alessi MC, and Burcelin R. 2007. Metabolic endotoxemia initiates obesity and insulin resistance. Diabetes 56:17611772. 10.2337/db06-1491

Cani PD, Bibiloni R, Knauf C, Waget A, Neyrinck AM, Delzenne NM, and Burcelin R. 2008. Changes in gut microbiota control metabolic endotoxemia-induced inflammation in high-fat diet-induced obesity and diabetes in mice. Diabetes 57:14701481. 10.2337/db07-1403

Cani PD, Possemiers S, Van de Wiele T, Guiot Y, Everard A, Rottier O, Geurts L, Naslain D, Neyrinck A, Lambert DM, Muccioli GG, and Delzenne NM. 2009. Changes in gut microbiota control inflammation in obese mice through a mechanism involving GLP-2-driven improvement of gut permeability. Gut 58:1091-1103. 10.1136/gut.2008.165886

Cheng L, Jin HM, Qiang YT, Wu SY, Yan C, Han MT, Xiao TF, Yan NN, An HZ, Zhou XM, Shao QX, and Xia S. 2016. High fat diet exacerbates dextran sulfate sodium induced colitis through disturbing mucosal dendritic cell homeostasis. International Immunopharmacology 40:1-10. 10.1016/j.intimp.2016.08.018

Cho I, and Blaser MJ. 2012. APPLICATIONS OF NEXT-GENERATION SEQUENCING The human microbiome: at the interface of health and disease. Nature Reviews Genetics 13:260-270. 10.1038/nrg3182 
Choudhri AF, Siddiqui A, Khan NR, and Cohen HL. 2015. Understanding Bibliometric Parameters and Analysis. Radiographics 35:736-746. 10.1148/rg.2015140036

D'Souza MJ, Wentzien DE, Bautista RC, and Gross CC. 2017. Investigation Of

357

358

359

360

361

362

363

364

365

366

367

368

369

370

371

372

373

374

375

376

377

378

379

380

381

382

383

384

385

386

387

388

389

390

391

392

393

394

395

396

397

398

399

de Clercq NC, Groen AK, Romijn JA, and Nieuwdorp M. 2016. Gut Microbiota in Obesity and Undernutrition. Advances in Nutrition 7:1080-1089. 10.3945/an.116.012914

de Vadder F, and Mithieux G. 2018. Gut-brain signaling in energy homeostasis: the unexpected role of microbiota-derived succinate. Journal of Endocrinology 236:R105R108. 10.1530/Joe-17-0542

Duranti S, Ferrario C, van Sinderen D, Ventura M, and Turroni F. 2017. Obesity and microbiota: an example of an intricate relationship. Genes and Nutrition 12:18. 10.1186/s12263-017-0566-2

Falagas ME, Pitsouni EI, Malietzis GA, and Pappas G. 2008. Comparison of PubMed, Scopus, Web of Science, and Google Scholar: strengths and weaknesses. Faseb Journal 22:338-342. 10.1096/fj.07-9492LSF

Feng WW, Zhao T, Mao GH, Wang W, Feng Y, Li F, Zheng DH, Wu HY, Jin D, Yang LQ, and Wu XY. 2015. Type 2 Diabetic Rats on Diet Supplemented With Chromium Malate Show Improved Glycometabolism, Glycometabolism-Related Enzyme Levels and Lipid Metabolism. PLoS One 10. ARTN e0125952

10.1371/journal.pone.0125952

Henao-Mejia J, Elinav E, Jin CC, Hao LM, Mehal WZ, Strowig T, Thaiss CA, Kau AL, Eisenbarth SC, Jurczak MJ, Camporez JP, Shulman GI, Gordon JI, Hoffman HM, and Flavell RA. 2012. Inflammasome-mediated dysbiosis regulates progression of NAFLD and obesity. Nature 482:179-185. 10.1038/nature10809

Kau AL, Ahern PP, Griffin NW, Goodman AL, and Gordon JI. 2011. Human nutrition, the gut microbiome and the immune system. Nature 474:327-336. 10.1038/nature10213

Khan A, Choudhury N, Uddin S, Hossain L, and Baur LA. 2016. Longitudinal trends in global obesity research and collaboration: a review using bibliometric metadata. Obesity Reviews 17:377-385. 10.1111/obr.12372

Kobyliak N, Conte C, Cammarota G, Haley AP, Styriak I, Gaspar L, Fusek J, Rodrigo L, and Kruzliak P. 2016. Probiotics in prevention and treatment of obesity: a critical view. Nutrition \& Metabolism 13:14. 10.1186/s12986-016-0067-0

Kulkarni AV, Aziz B, Shams I, and Busse JW. 2009. Comparisons of citations in Web of Science, Scopus, and Google Scholar for articles published in general medical journals. Jama 302:1092-1096.

Kvit KB, and Kharchenko NV. 2017. Gut microbiota changes as a risk factor for obesity. Wiadomosci Lekarskie 70:231-235.

Le Chatelier E, Nielsen T, Qin JJ, Prifti E, Hildebrand F, Falony G, Almeida M, Arumugam M, Batto JM, Kennedy S, Leonard P, Li JH, Burgdorf K, Grarup N, Jorgensen T, Brandslund I, Nielsen HB, Juncker AS, Bertalan M, Levenez F, Pons N, Rasmussen S, Sunagawa S, Tap J, Tims S, Zoetendal EG, Brunak S, Clement K, Dore J, Kleerebezem M, Kristiansen K, Renault P, Sicheritz-Ponten T, de Vos WM, Zucker JD, Raes J, Hansen T, Bork P, Wang J, Ehrlich SD, Pedersen O, and Consortium M. 2013. 
400

401

402

403

404

405

406

407

408

409

410

411

412

413

414

415

416

417

418

419

420

421

422

423

424

425

426

427

428

429

430

431

432

433

434

435

436

437

438

439

440

441

442

443

444

445

Richness of human gut microbiome correlates with metabolic markers. Nature 500:541-+. 10.1038/nature12506

Ley RE, Bäckhed F, Turnbaugh P, Lozupone CA, Knight RD, and Gordon JI. 2005. Obesity alters gut microbial ecology. Proceedings of the National Academy of Sciences of the United States of America 102:11070-11075.

Ley RE, Turnbaugh PJ, Klein S, and Gordon JI. 2006. Microbial ecology: human gut microbes associated with obesity. Nature 444:1022-1023. 10.1038/4441022a

Li F, Dong Y, Shen HJ, Lu RZ, Yin SQ, Tian WH, Wang SH, and Xing GW. 2017a. Tolerance to dichloroacetonitrile-induced neurotoxicity in streptozotocin-induced diabetic rats. Environmental Toxicology and Pharmacology 56:61-67. 10.1016/j.etap.2017.08.037

Li J, Riaz Rajoka MS, Shao D, Jiang C, Jin M, Huang Q, Yang H, and Shi J. 2017b. Strategies to increase the efficacy of using gut microbiota for the modulation of obesity. Obesity Reviews. 10.1111/obr.12590

Li JV, Ashrafian H, Bueter M, Kinross J, Sands C, le Roux CW, Bloom SR, Darzi A, Athanasiou T, Marchesi JR, Nicholson JK, and Holmes E. 2011. Metabolic surgery profoundly influences gut microbial-host metabolic cross-talk. Gut 60:1214-1223. 10.1136/gut.2010.234708

Nasreddine L, Hwalla N, Saliba A, Akl C, and Naja F. 2017. Prevalence and Correlates of Preschool Overweight and Obesity Amidst the Nutrition Transition: Findings from a National Cross-Sectional Study in Lebanon. Nutrients 9. 10.3390/nu9030266

O'Hara AM, and Shanahan F. 2006. The gut flora as a forgotten organ. Embo Reports 7:688-693. 10.1038/sj.embor.7400731

Omari-Siaw E, Zhu Y, Wang H, Peng W, Firempong CK, Wang YW, Cao X, Deng $\mathrm{W}, \mathrm{Yu} \mathrm{J}$, and $\mathrm{Xu} \mathrm{X}$. 2016. Hypolipidemic potential of perillaldehyde-loaded selfnanoemulsifying delivery system in high-fat diet induced hyperlipidemic mice: Formulation, in vitro and in vivo evaluation. Eur J Pharm Sci 85:112-122. 10.1016/j.ejps.2016.02.003

Ozturk Y. 2017. Etiology and comorbidities of childhood obesity. Turkish Journal of Gastroenterology 28:149-151. 10.5152/tjg.2017.010317

Pritchard J. 1969. Statistical bibliography or bibliometrics? Journal of documentation 25:348-349.

Qin J, Li R, Raes J, Arumugam M, Burgdorf KS, Manichanh C, Nielsen T, Pons N, Levenez F, Yamada T, Mende DR, Li J, Xu J, Li S, Li D, Cao J, Wang B, Liang H, Zheng H, Xie Y, Tap J, Lepage P, Bertalan M, Batto JM, Hansen T, Le Paslier D, Linneberg A, Nielsen HB, Pelletier E, Renault P, Sicheritz-Ponten T, Turner K, Zhu H, Yu C, Li S, Jian M, Zhou Y, Li Y, Zhang X, Li S, Qin N, Yang H, Wang J, Brunak S, Dore J, Guarner F, Kristiansen K, Pedersen O, Parkhill J, Weissenbach J, Meta HITC, Bork P, Ehrlich SD, and Wang J. 2010. A human gut microbial gene catalogue established by metagenomic sequencing. Nature 464:59-65. 10.1038/nature08821

Ridaura VK, Faith JJ, Rey FE, Cheng JY, Duncan AE, Kau AL, Griffin NW, Lombard V, Henrissat B, Bain JR, Muehlbauer MJ, Ilkayeva O, Semenkovich CF, Funai K, Hayashi DK, Lyle BJ, Martini MC, Ursell LK, Clemente JC, Van Treuren W, Walters WA, Knight R, Newgard CB, Heath AC, and Gordon JI. 2013. Gut Microbiota from Twins Discordant for Obesity Modulate Metabolism in Mice. Science 341:1079-U1049. 
446

447

448

449

450

451

452

453

454

455

456

457

458

459

460

461

462

463

464

465

466

467

468

469

470

471

472

473

474

475

476

477

478

479

480

481

482

483

484 10.1126/science. 1241214

SC B. 1948. Documentation. London: Crosby Lockwood.

Tremaroli V, and Bäckhed F. 2012. Functional interactions between the gut microbiota and host metabolism. Nature 489:242-249.

Turnbaugh PJ, Baeckhed F, Fulton L, and Gordon JI. 2008. Diet-induced obesity is linked to marked but reversible alterations in the mouse distal gut microbiome. Cell Host \& Microbe 3:213-223. 10.1016/j.chom.2008.02.015

Turnbaugh PJ, Hamady M, Yatsunenko T, Cantarel BL, Duncan A, Ley RE, Sogin ML, Jones WJ, Roe BA, Affourtit JP, Egholm M, Henrissat B, Heath AC, Knight R, and Gordon JI. 2009a. A core gut microbiome in obese and lean twins. Nature 457:480-484. 10.1038 /nature 07540

Turnbaugh PJ, Ley RE, Mahowald MA, Magrini V, Mardis ER, and Gordon JI. 2006. An obesity-associated gut microbiome with increased capacity for energy harvest. Nature 444:1027-1031. 10.1038/nature05414

Turnbaugh PJ, Ridaura VK, Faith JJ, Rey FE, Knight R, and Gordon JI. 2009b. The Effect of Diet on the Human Gut Microbiome: A Metagenomic Analysis in Humanized Gnotobiotic Mice. Science Translational Medicine 1:6ra14. ARTN 6ra14

10.1126/scitranslmed.3000322

van Eck NJ, and Waltman L. 2010. Software survey: VOSviewer, a computer program for bibliometric mapping. Scientometrics 84:523-538. 10.1007/s11192-0090146-3

Vijay-Kumar M, Aitken JD, Carvalho FA, Cullender TC, Mwangi S, Srinivasan S, Sitaraman SV, Knight R, Ley RE, and Gewirtz AT. 2010. Metabolic syndrome and altered gut microbiota in mice lacking Toll-like receptor 5. Science 328:228-231.

Vioque J, Ramos JM, Navarrete-Munoz EM, and Garcia-de-la-Hera M. 2010. A bibliometric study of scientific literature on obesity research in PubMed (1988-2007). Obesity Reviews 11:603-611. 10.1111/j.1467-789X.2009.00647.x

Wang HY, Li Q, Deng WW, Omari-siaw E, Wang QL, Wang SC, Wang SL, Cao X, $\mathrm{Xu} \mathrm{XM}$, and Yu JN. 2015. Self-Nanoemulsifying Drug Delivery System of transCinnamic acid: Formulation Development and Pharmacodynamic Evaluation in Alloxaninduced Type 2 Diabetic Rat Model. Drug Development Research 76:82-93. $10.1002 /$ ddr. 21244

Zhang MH, Feng L, Zhu MM, Gu JF, Jiang J, Cheng XD, Ding SM, Wu C, and Jia XB. 2014. The anti-inflammation effect of Moutan Cortex on advanced glycation end products-induced rat mesangial cells dysfunction and High-glucose-fat diet and streptozotocin-induced diabetic nephropathy rats. $J$ Ethnopharmacol 151:591-600. 10.1016/j.jep.2013.11.015 


\section{Figure legends}

486 Fig. 1 Annual and accumulated publications of intestinal microbiota and obesity (A), 487 obesity research (B), and the percentage of intestinal microbiota related publications in the 488 obesity research $(\mathbf{C})$.

489

490

Fig. 2 General information of retrieved 3446 publications on gut microbiota and obesity. (A)

491

Document types distribution; (B) Source types distribution; (C) Subjects distribution;

492

493

494

495

496

497

498

499

500

501

502 503 504 505

506

Fig. 3 Citation analysis of 85 authors with at least 10 publications. Thicker lines indicate stronger collaborations. Authors represented with larger circle size or font size had relatively more citations.

Fig. 4 Geographical distribution map of publications on intestinal microbiota in obesity research.

Fig. 5 Correlations between the publication number of bariatric intestinal microbiota in obesity research and (A) GDP ( $\mathrm{r}=0.89, p<0.0001)$, (B) HDI ( $\mathrm{r}=0.32, p<0.001)$, (C) PN ( $\mathrm{r}=0.27$, $p<0.05)$, and (D) PPP ( $p=0.08)$. Abbreviations: GDP, gross domestic product; HDI, human development index; PN, population number; PPP, purchasing power parity (gross domestic product per capita).

Fig. 6 Density map of journals citation analysis. 127 journals were included in this analysis 
508 with a minimum productivity of 5 publications in this field. Journals with the higher number of 509 citations have darker spot.

510

511 Fig. 7 Density map of most frequently encountered terms extracted from the titles and 512 abstracts of retrieved publications. A number of 195 terms met the threshold with a minimum 513 number of occurrences as 100 . The larger circle size or font size indicates higher occurrence.

514

515 


\section{Figure 1 (on next page)}

Annual and accumulated publications of intestinal microbiota and obesity (A), obesity research (B), and the percentage of intestinal microbiota related publications in the obesity research (C). 
$\mathbf{A}$

Literature numbers of intestinal microbiota in obesity research

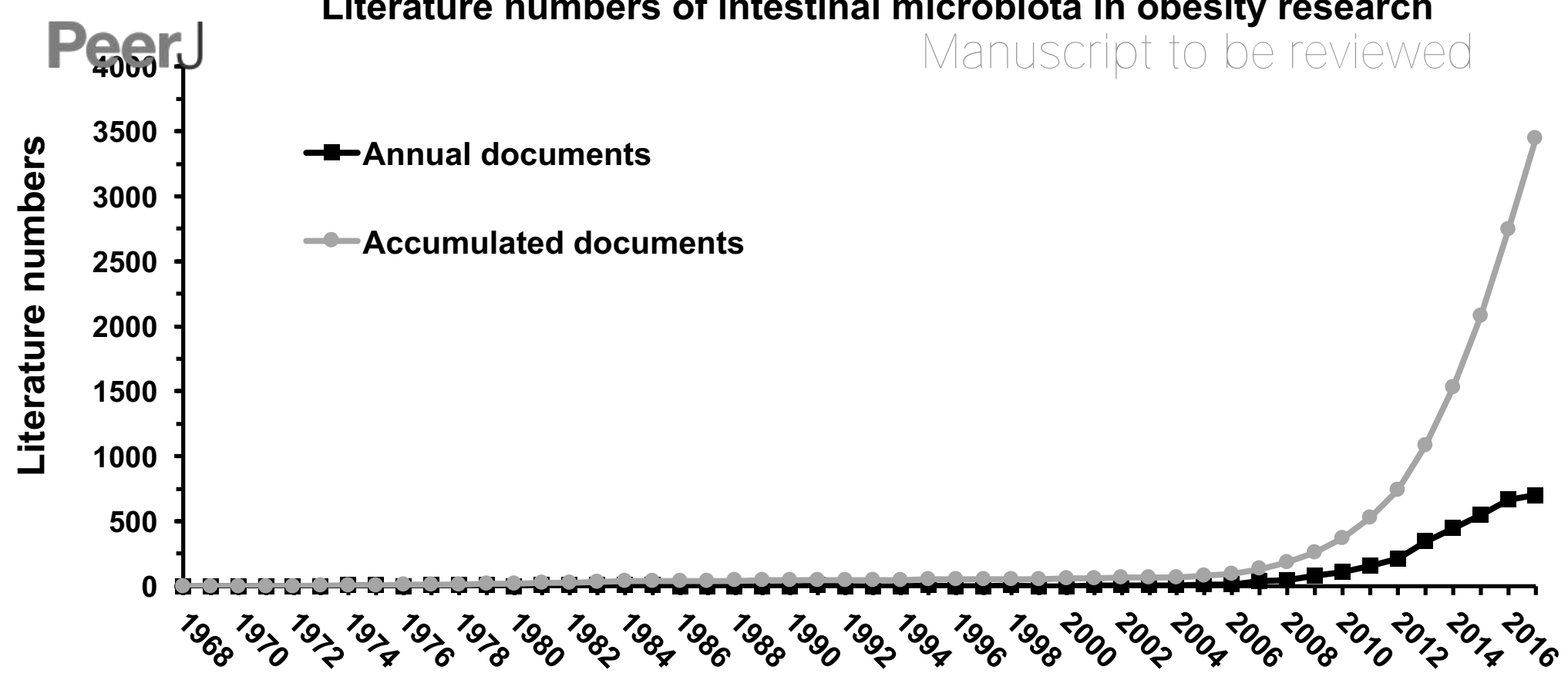

B

Literature numbers of obesity research

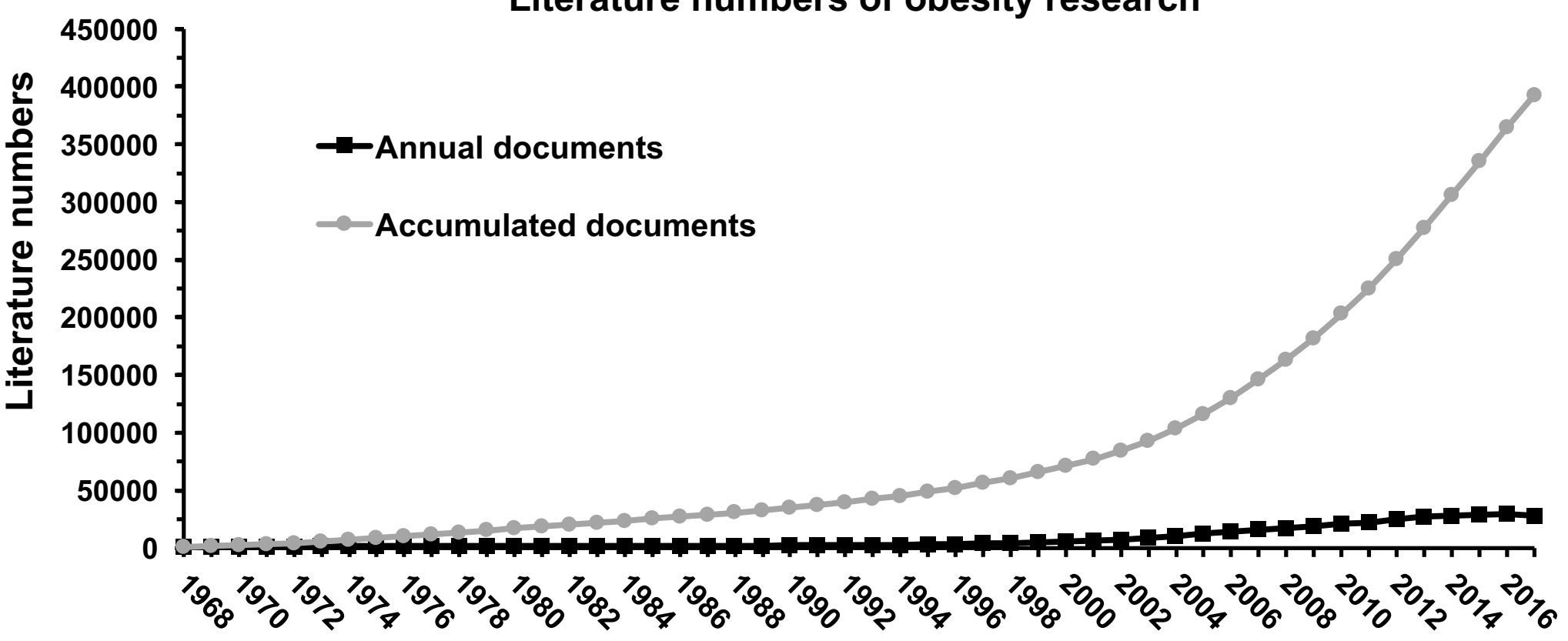

C

Percentage of intestinal microbiota in obesity research

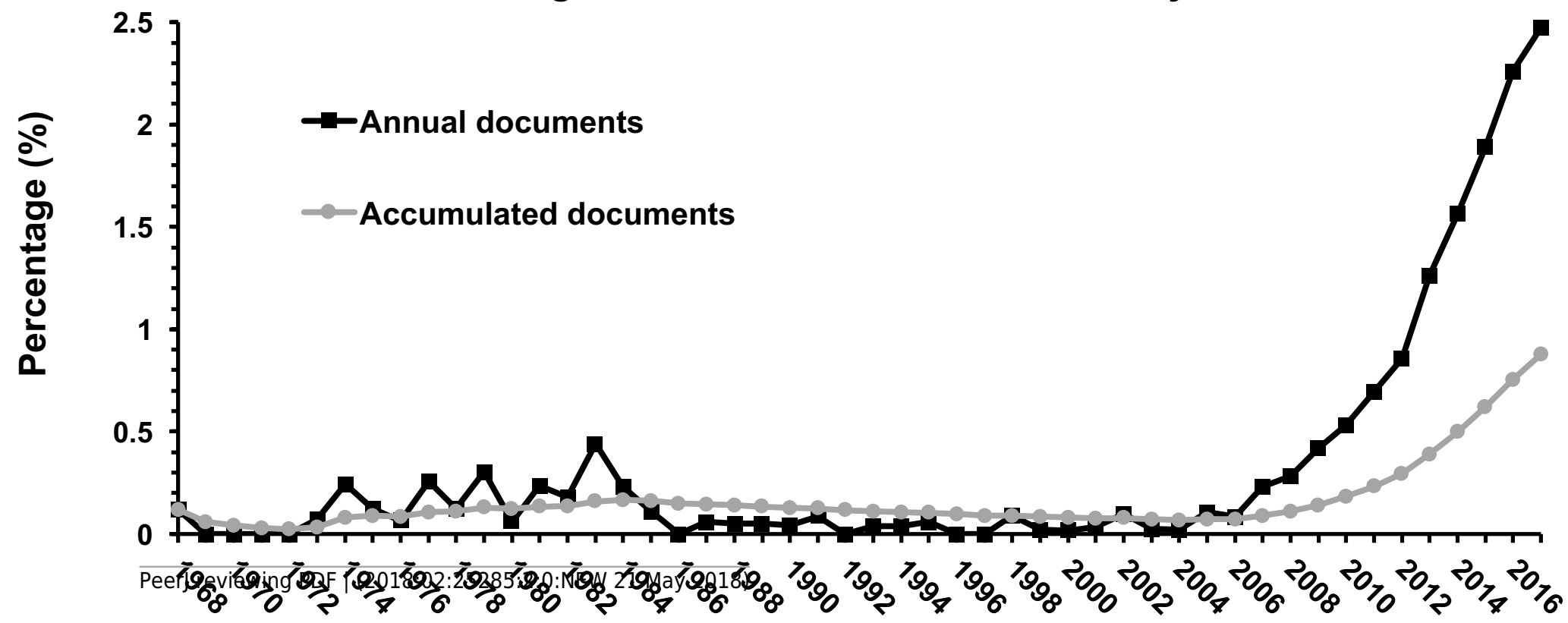


Figure 2 (on next page)

General information of retrieved 3446 publications on gut microbiota and obesity.

(A) Document types distribution; (B) Source types distribution; (C) Subjects distribution; (D) Languages distribution. 


\section{Docunieffirtypes distribution}

Literature numbers

Article

Review

Book Chapter

Note

Editorial

Conference Paper

$$
\begin{array}{r|r}
\text { Short Survey } & 82 \\
\text { Letter } & 33 \\
\text { Article in Press } & 21 \\
\text { Erratum } & 8 \\
\text { Book } & 6
\end{array}
$$

\section{C}

Subjects distribution

Literature numbers

$$
\text { Medicine }
$$

Biochemistry, Genetics and Molecular Biology
Nursing
Immunology and Microbiology

Biochemistry, Genetics and Molecular Biology
Nursing
Immunology and Microbiology Immunology and Biological Sciences Agricultural and Biological Sciences

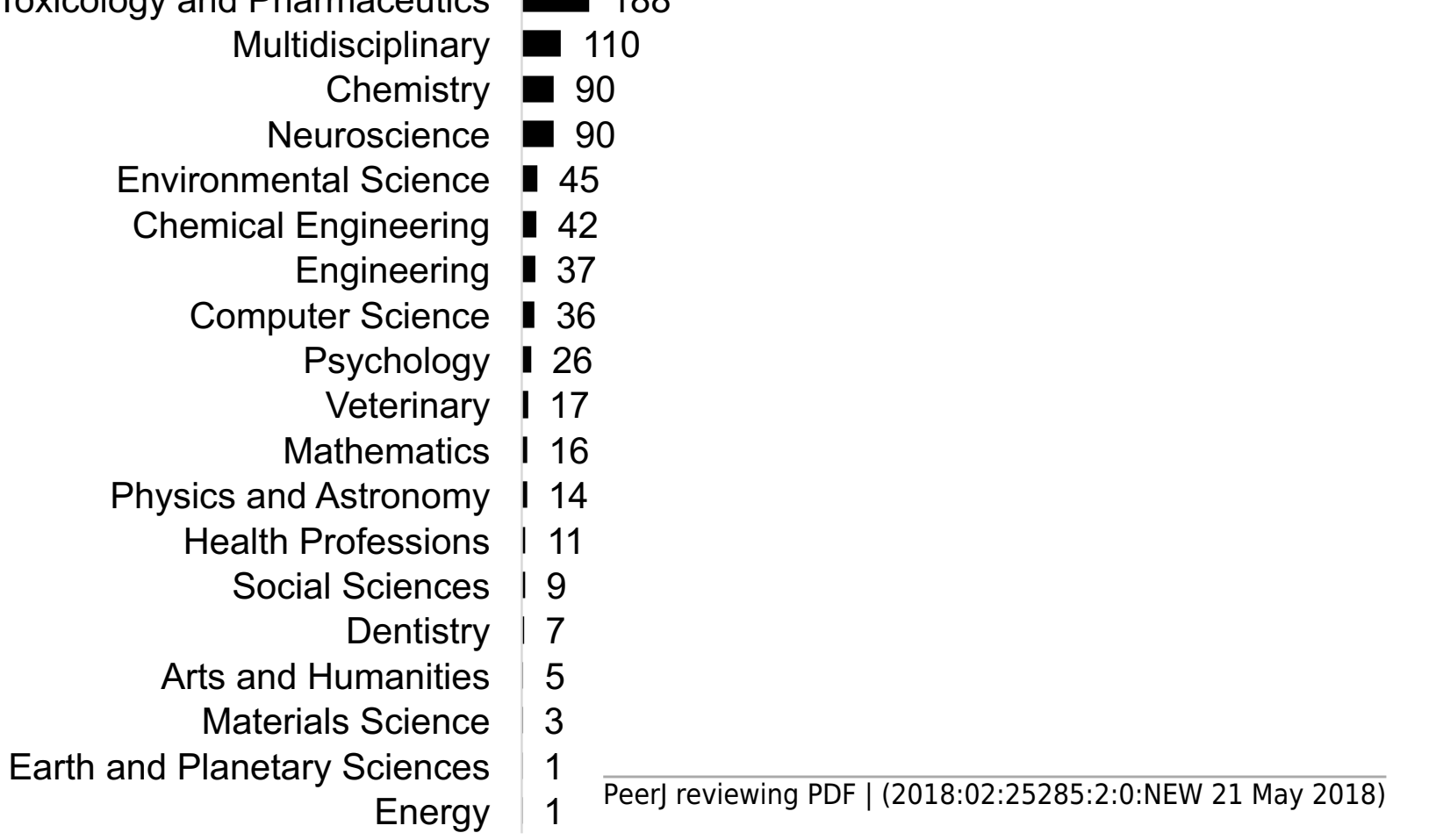

\section{B}

Journals

Books

94

Book series

72

\begin{tabular}{l|l} 
Conference proceedings & 7
\end{tabular}

Trade publications 3
D

Languages distribution

Literature numbers

\begin{tabular}{r|l} 
English & \\
French & 65 \\
Chinese & 37 \\
German & 33 \\
Spanish & 24 \\
Russian & 14 \\
Japanese & 13 \\
Polish & 10 \\
Czech & 8 \\
Korean & 6 \\
Hungarian & 5 \\
Italian & 5 \\
Portuguese & 4 \\
Dutch & 3 \\
Turkish & 3 \\
Croatian & 2 \\
Finnish & 2 \\
Danish & 1 \\
Greek & 1 \\
Persian & 1 \\
Romanian & 1 \\
Slovak & 1 \\
Slovenian & 1
\end{tabular}




\section{Figure 3 (on next page)}

Citation analysis of 85 authors with at least 10 publications.

Thicker lines indicate stronger collaborations. Authors represented with larger circle size or font size had relatively more citations. 
collado m.c.

isolauri e.

salminen $\mathrm{s}$.

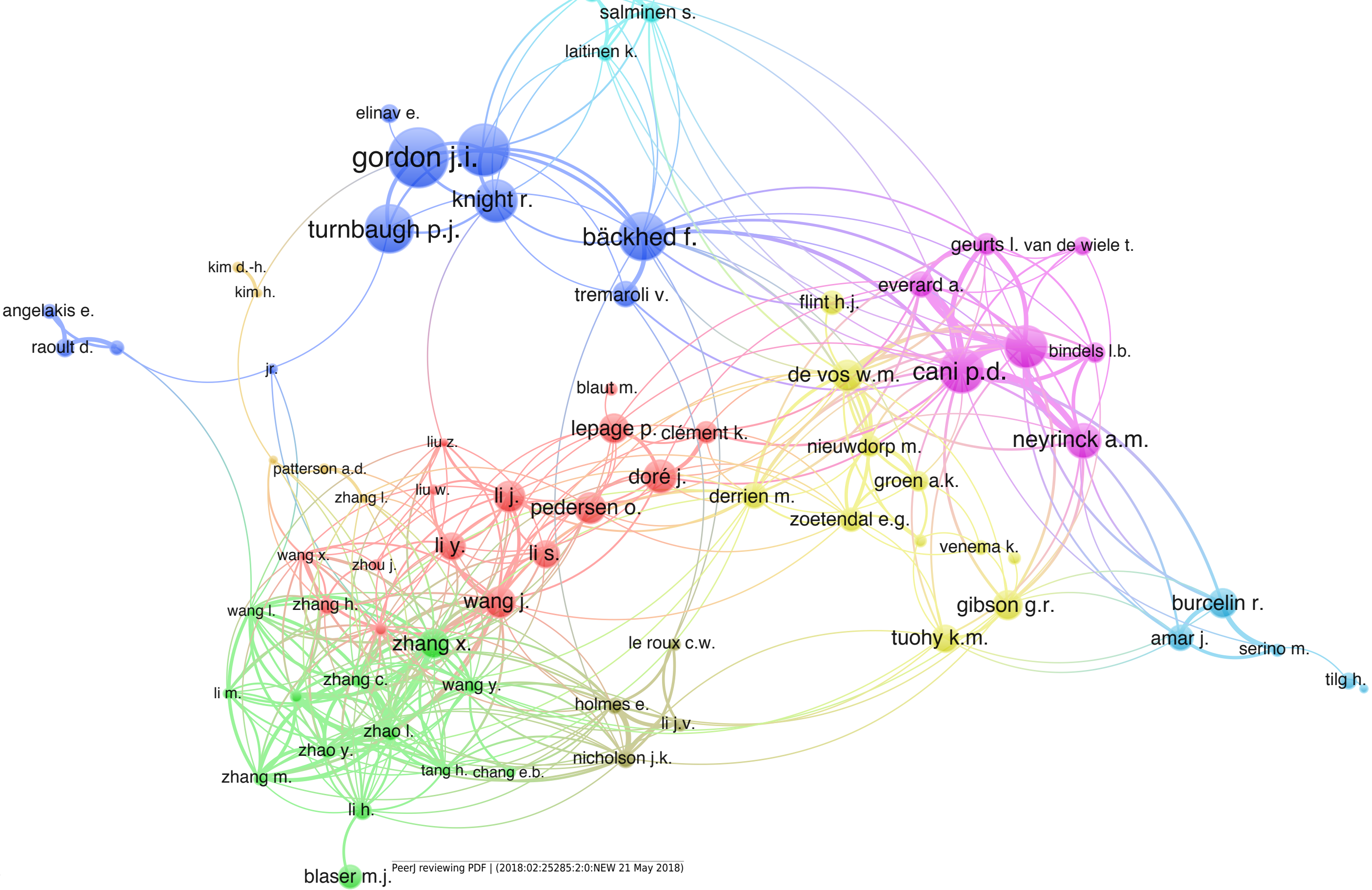


Figure 4

Geographical distribution map of publications on intestinal microbiota in obesity research.

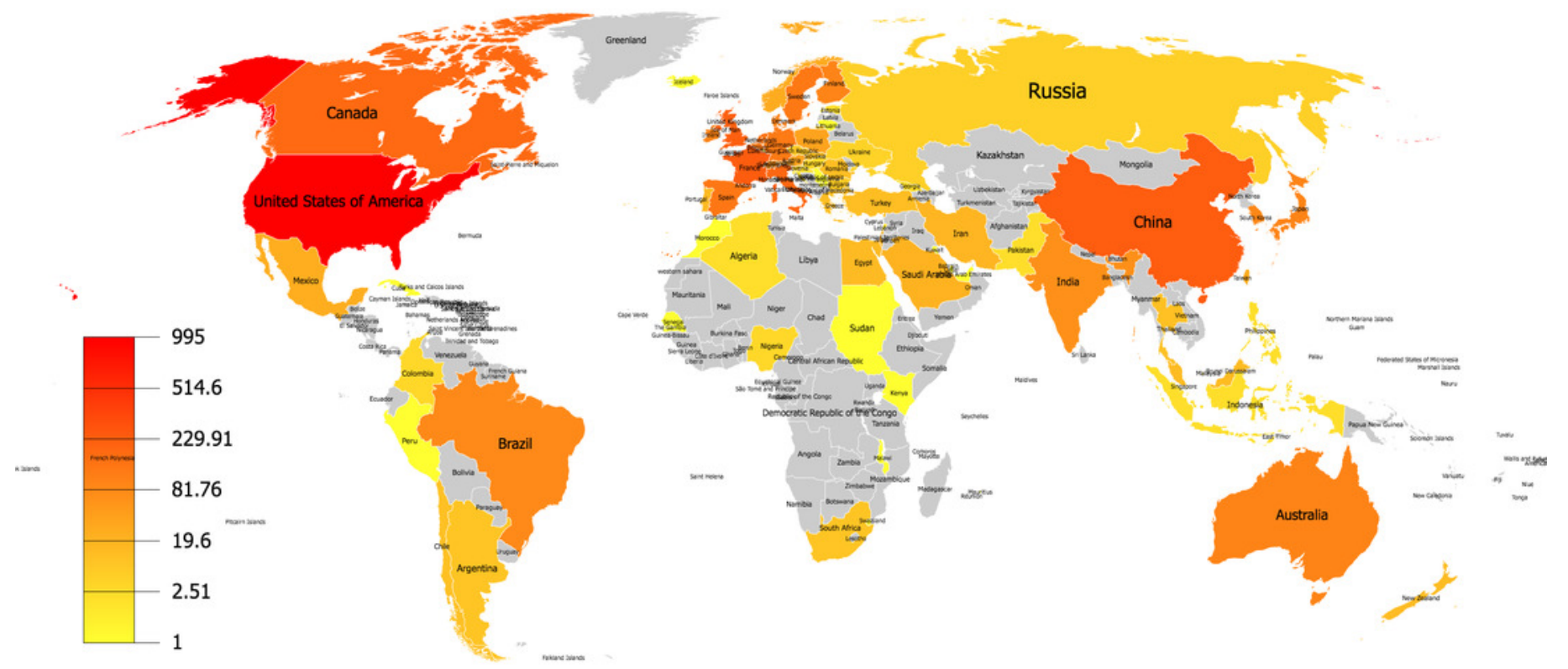




\section{Figure 5(on next page)}

Correlations between the publication number of bariatric intestinal microbiota in obesity research and (A) GDP ( $r=0.89, p<0.0001)$, (B) HDI $(r=0.32, p<0.001)$, (C) PN $(r=0.27$, $p<0.05)$, and (D) PPP $(p=0.08)$.

Abbreviations: GDP, gross domestic product; $\mathrm{HDI}$, human development index; PN, population number; PPP, purchasing power parity (gross domestic product per capita). 
B Manuscript to be reviewed
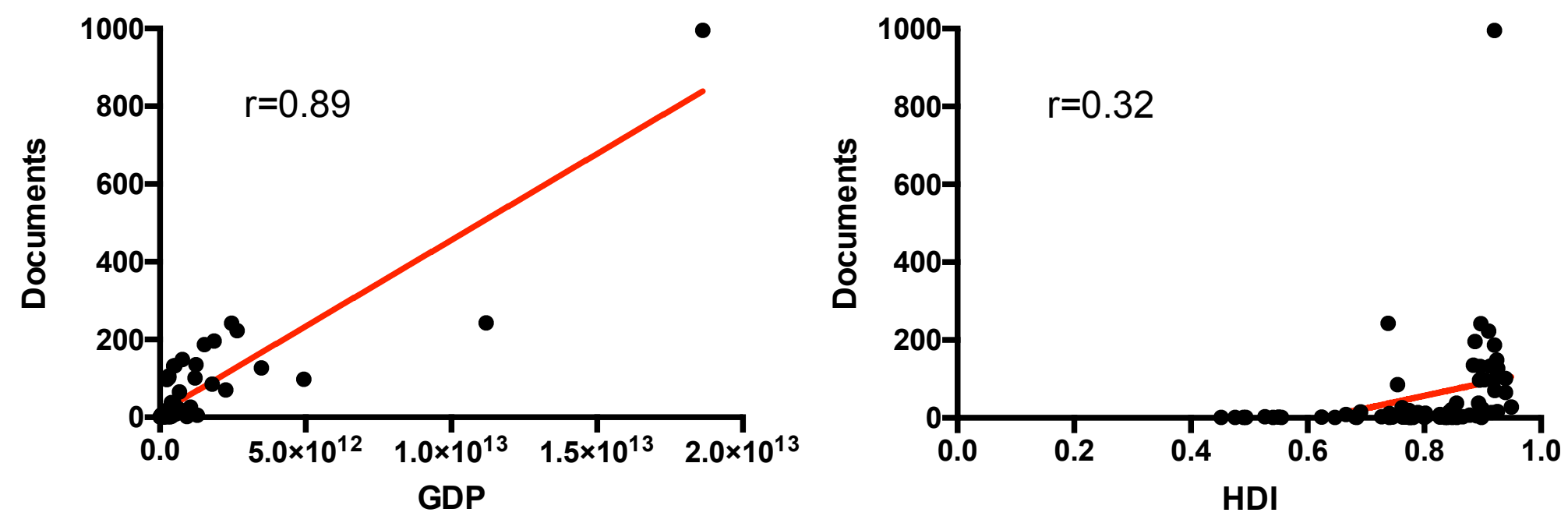

C
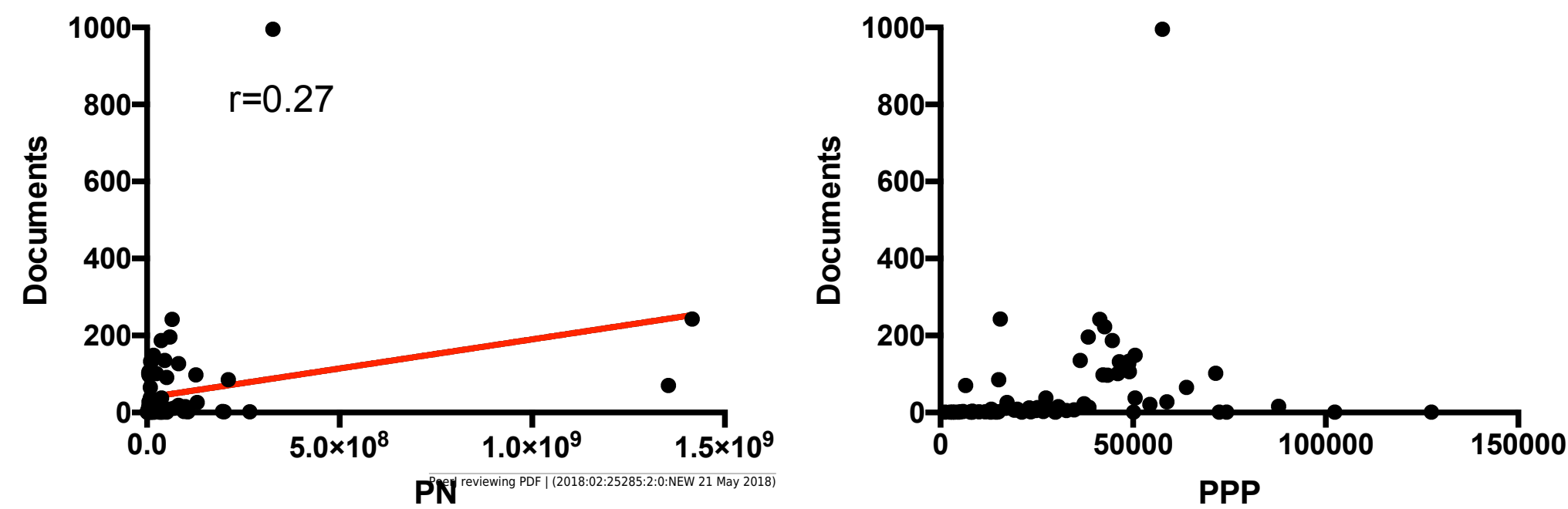
Figure $\mathbf{6}$ (on next page)

Density map of journals citation analysis.

127 journals were included in this analysis with a minimum productivity of 5 publications in this field. Journals with the higher number of citations have darker spots. 
frontiers in physiology

urrent opinion in gastroenter

\section{nutrition research reviews}

\section{journal of hepatology}

\begin{abstract}
(n)
\end{abstract}
journal of nutrition

alimentary pharmacology and th

critical reviews in food scien

\section{journal of proteome research}

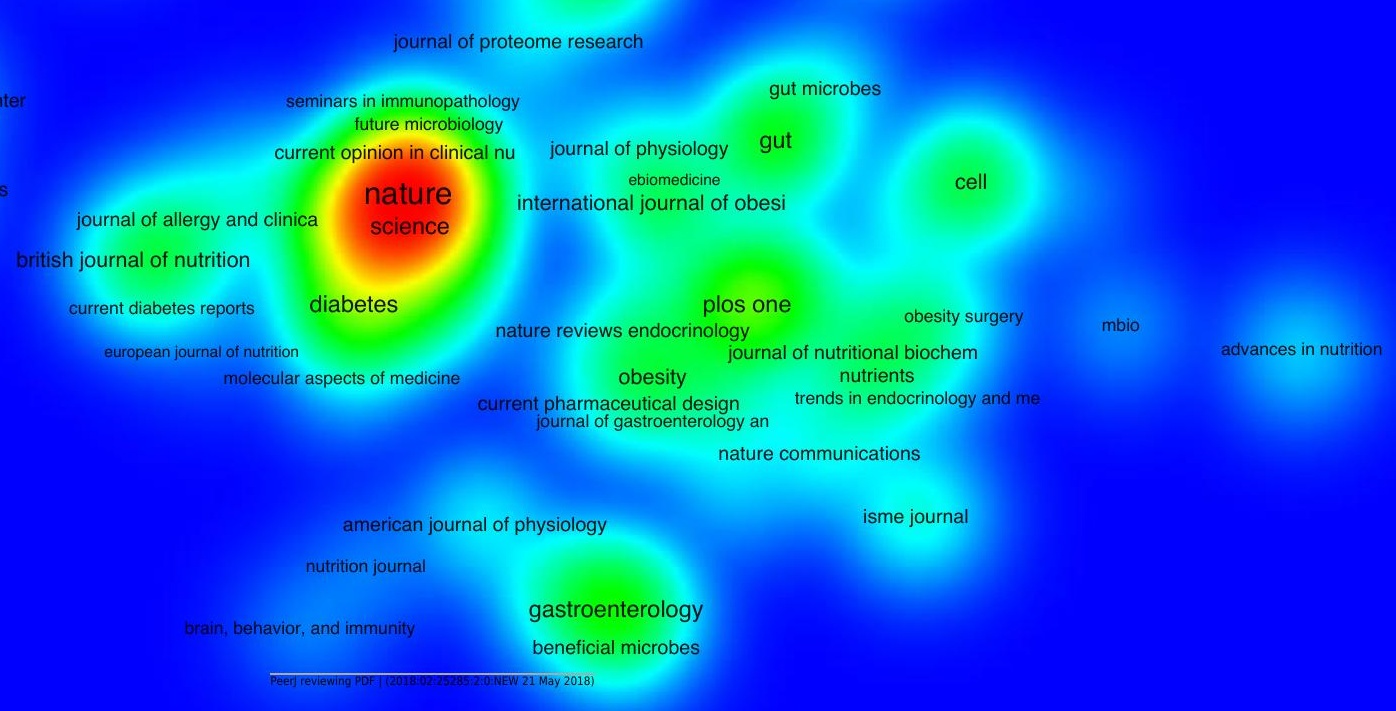

nature reviews microbiology

\section{american journal of clinical $n$}




\section{Figure 7 (on next page)}

Density map of most frequently encountered terms extracted from the titles and abstracts of retrieved publications.

A number of 195 terms met the threshold with a minimum number of occurrences as 100 . The larger circle size or font size indicates higher occurrence. 


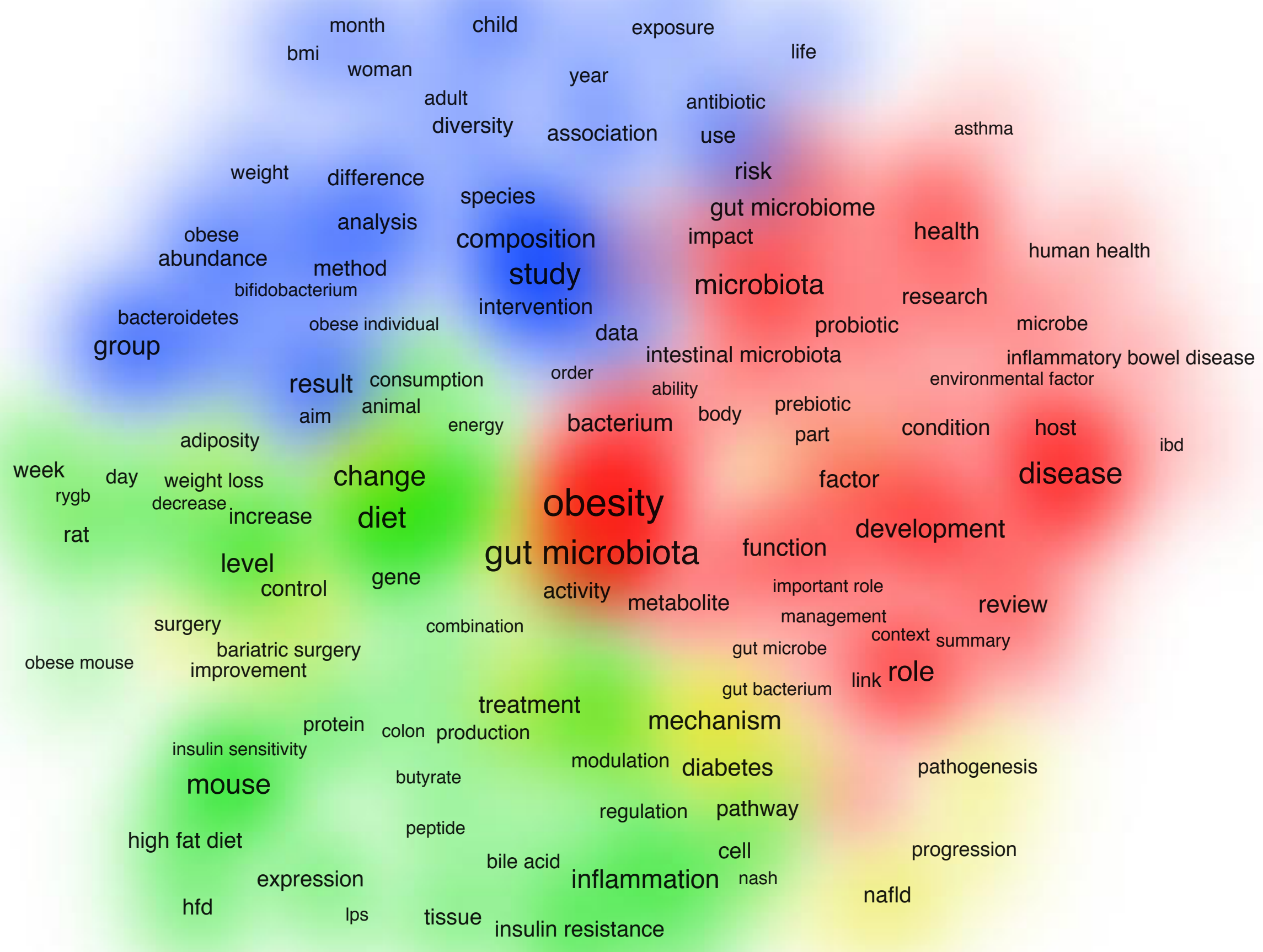




\section{Table $\mathbf{1}$ (on next page)}

Top 20 cited articles on gut microbiota and obesity from inception to 2017 
Table 1. Top 20 cited articles on gut microbiota and obesity from inception to 2017

\begin{tabular}{|c|c|c|c|c|c|c|}
\hline $\begin{array}{l}\text { SC } \\
\text { R }\end{array}$ & Article & Title & Year & Source title & Cited by & IF \\
\hline $1^{\text {st }}$ & $\begin{array}{l}\text { Turnbaugh et } \\
\text { al. } 2006\end{array}$ & $\begin{array}{l}\text { An obesity-associated gut microbiome with increased } \\
\text { capacity for energy harvest }\end{array}$ & 2006 & Nature & 3961 & $\begin{array}{c}40.13 \\
7\end{array}$ \\
\hline $2^{\text {nd }}$ & $\begin{array}{l}\text { Qin et al. } \\
2010\end{array}$ & $\begin{array}{l}\text { A human gut microbial gene catalogue established by } \\
\text { metagenomic sequencing }\end{array}$ & 2010 & Nature & 3724 & $\begin{array}{c}40.13 \\
7\end{array}$ \\
\hline $3^{\text {rd }}$ & $\begin{array}{l}\text { Turnbaugh et } \\
\text { al. } 2009 \mathrm{a}\end{array}$ & A core gut microbiome in obese and lean twins & 2009 & Nature & 3072 & $\begin{array}{c}40.13 \\
7\end{array}$ \\
\hline $4^{\text {th }}$ & $\begin{array}{l}\text { Ley et al. } \\
2006\end{array}$ & $\begin{array}{l}\text { Microbial ecology: Human gut microbes associated with } \\
\text { obesity }\end{array}$ & 2006 & Nature & 3023 & $\begin{array}{c}40.13 \\
7\end{array}$ \\
\hline $5^{\text {th }}$ & $\begin{array}{l}\text { Bäckhed et al. } \\
2004\end{array}$ & $\begin{array}{l}\text { The gut microbiota as an environmental factor that } \\
\text { regulates fat storage }\end{array}$ & 2004 & PNAS & 2350 & 9.661 \\
\hline $6^{\text {th }}$ & $\begin{array}{l}\text { Ley et al. } \\
2005\end{array}$ & Obesity alters gut microbial ecology & 2005 & PNAS & 2292 & 9.661 \\
\hline $7^{\text {th }}$ & $\begin{array}{l}\text { Bäckhed et al. } \\
2005\end{array}$ & Host-bacterial mutualism in the human intestine & 2005 & Science & 2174 & $\begin{array}{c}37.20 \\
5\end{array}$ \\
\hline $8^{\text {th }}$ & $\begin{array}{l}\text { Cani et al. } \\
2007\end{array}$ & $\begin{array}{l}\text { Metabolic endotoxemia initiates obesity and insulin } \\
\text { resistance }\end{array}$ & 2007 & Diabetes & 1986 & 8.684 \\
\hline $9^{\text {th }}$ & $\begin{array}{l}\text { Cani et al. } \\
2008\end{array}$ & $\begin{array}{l}\text { Changes in gut microbiota control metabolic } \\
\text { endotoxemia-induced inflammation in high-fat diet- } \\
\text { induced obesity and diabetes in mice }\end{array}$ & 2008 & Diabetes & 1521 & 8.684 \\
\hline $10^{\text {th }}$ & $\begin{array}{l}\text { Tremaroli \& } \\
\text { Bäckhed } 2012\end{array}$ & $\begin{array}{l}\text { Functional interactions between the gut microbiota and } \\
\text { host metabolism }\end{array}$ & 2012 & Nature & 1198 & 9.661 \\
\hline $11^{\text {st }}$ & $\begin{array}{l}\text { Turnbaugh. et } \\
\text { al. } 2009 \mathrm{~b}\end{array}$ & $\begin{array}{l}\text { The effect of diet on the human gut microbiome: A } \\
\text { metagenomic analysis in humanized gnotobiotic mice }\end{array}$ & 2009 & $\begin{array}{l}\text { Science } \\
\text { Translationa } \\
1 \text { Medicine }\end{array}$ & 1091 & $\begin{array}{c}16.76 \\
1\end{array}$ \\
\hline $12^{\text {nd }}$ & $\begin{array}{l}\text { Bäckhed et al. } \\
2007\end{array}$ & $\begin{array}{l}\text { Mechanisms underlying the resistance to diet-induced } \\
\text { obesity in germ-free mice }\end{array}$ & 2007 & PNAS & 1081 & 9.661 \\
\hline $13^{\text {rd }}$ & $\begin{array}{l}\text { Turnbaugh et } \\
\text { al. } 2008\end{array}$ & $\begin{array}{l}\text { Diet-Induced Obesity Is Linked to Marked but Reversible } \\
\text { Alterations in the Mouse Distal Gut Microbiome }\end{array}$ & 2008 & $\begin{array}{c}\text { Cell Host } \\
\text { and Microbe }\end{array}$ & 1046 & $\begin{array}{c}14.94 \\
6\end{array}$ \\
\hline $14^{\text {th }}$ & Vijay-Kumar & Metabolic syndrome and altered gut microbiota in mice & 2010 & Science & 996 & 37.20 \\
\hline
\end{tabular}


et al. $2010 \quad$ lacking toll-like receptor 5

$15^{\text {th }}$ O'Hara \&

The gut flora as a forgotten organ

2006

EMBO

949

8.568

Shanahan

2006

$16^{\text {th }}$ Cani et al.

Changes in gut microbiota control inflammation in obese

Reports

2009 mice through a mechanism involving GLP-2-driven improvement of gut permeability

$17^{\text {th }} \quad$ Le Chatelier et al. 2013

Richness of human gut microbiome correlates with metabolic markers

$18^{\text {th }}$ Kau et al. 2011

Human nutrition, the gut microbiome and the immune system

$19^{\text {th }}$ Henao-Mejia et al. 2012

Inflammasome-mediated dysbiosis regulates progression of NAFLD and obesity

$20^{\text {th }}$ Ridaura et al. 2013

Gut microbiota from twins discordant for obesity modulate metabolism in mice

2009

Gut

903

16.65

8

Nature

900

40.13

2011

Nature

885

2012

Nature

884

40.13

7

40.13

2013

Science

882

Abbreviation: SCR, standard competition ranking. Equal items were given the same ranking number, and then a gap is left in the ranking numbers; PNAS, Proceedings of the National Academy of Sciences of the United States of America; IF, impact factor.

* Data extracted from Journal Citation Reports, Thomson Reuters, 2016. 


\section{Table 2 (on next page)}

Top 20 prolific institutions in publishing papers on gut microbiota and obesity 
Table 2. Top 20 prolific institutions in publishing papers on gut microbiota and obesity

\begin{tabular}{clccc}
\hline \multicolumn{1}{c}{ Institution } & Country & Documents & $\% \mathrm{~N}=3056$ \\
\hline $1^{\text {st }}$ & University College Cork & Ireland & 122 & 4.0 \\
$2^{\text {nd }}$ & Inserm & France & 109 & 3.6 \\
$3^{\text {rd }}$ & Universite Catholique de Louvain & Belgium & 95 & 3.1 \\
$4^{\text {th }}$ & Kobenhavns Universitet & Denmark & 87 & 2.8 \\
$5^{\text {th }}$ & Goteborgs Universitet & Sweden & 74 & 2.4 \\
$6^{\text {th }}$ & Wageningen University and Research Centre & Netherlands & 60 & 2.0 \\
$7^{\text {th }}$ & INRA Institut National de La Recherche Agronomique & France & 53 & 1.7 \\
$7^{\text {th }}$ & The Wallenberg Laboratory & Sweden & 53 & 1.7 \\
$9^{\text {th }}$ & Imperial College London & UK & 49 & 1.6 \\
$10^{\text {th }}$ & VA Medical Center & US & 46 & 1.5 \\
$11^{\text {st }}$ & Harvard Medical School & US & 45 & 1.5 \\
$11^{\text {st }}$ & Helsingin Yliopisto & Finland & 45 & 1.5 \\
$13^{\text {rd }}$ & CNRS Centre National de la Recherche Scientifique & France & 41 & 1.3 \\
$14^{\text {th }}$ & Novo Nordisk Foundation & Denmark & 40 & 1.3 \\
$14^{\text {th }}$ & Consejo Superior de Investigaciones Científicas & Spain & 40 & 1.3 \\
$16^{\text {th }}$ & Chinese Academy of Sciences & China & 39 \\
$16^{\text {th }}$ & Shanghai Jiao Tong University & China & 39 & 1.3 \\
$18^{\text {th }}$ & University of Calgary & Canada & 37 & 1.3 \\
$19^{\text {th }}$ & Maastricht University & Netherlands & 36 & 1.2 \\
$20^{\text {th }}$ & University of Chicago & US & 33 & 1.2 \\
\hline & & & 1.1 \\
\hline
\end{tabular}




\section{Table 3 (on next page)}

Top 20 prolific journals in publishing papers on gut microbiota and obesity 
1 Table 3. Top 20 prolific journals in publishing papers on gut microbiota and obesity

\begin{tabular}{clccc}
\hline SCR & \multicolumn{1}{c}{ Journals } & Documents & $\%$ N=3056 & IF \\
\hline $1^{\text {st }}$ & Plos One & 106 & 3.5 & 2.806 \\
$2^{\text {nd }}$ & Scientific Reports & 46 & 1.5 & 4.259 \\
$3^{\text {td }}$ & British Journal of Nutrition & 43 & 1.4 & 3.706 \\
$4^{\text {th }}$ & Nutrients & 42 & 1.4 & 3.55 \\
$5^{\text {th }}$ & Gut Microbes & 40 & 1.3 & NA \\
$5^{\text {th }}$ & Cell Metabolism & 37 & 1.2 & 18.164 \\
$7^{\text {th }}$ & Frontiers in Microbiology & 36 & 1.2 & 4.076 \\
$7^{\text {th }}$ & World Journal of Gastroenterology & 36 & 1.2 & 3.365 \\
$9^{\text {th }}$ & Gastroenterology & 33 & 1.1 & 18.392 \\
$10^{\text {th }}$ & Nature & 32 & 1.0 & 40.137 \\
$11^{\text {st }}$ & Beneficial Microbes & 30 & 1.0 & 2.923 \\
$11^{\text {st }}$ & Molecular Nutrition and Food Research & 30 & 1.0 & 4.323 \\
$11^{\text {st }}$ & Nature Reviews Gastroenterology and Hepatology & 30 & 1.0 & 13.678 \\
$14^{\text {th }}$ & Gut & 29 & 0.9 & 16.658 \\
$14^{\text {th }}$ & International Journal of Obesity & 29 & 0.9 & 5.487 \\
$16^{\text {th }}$ & American Journal of Clinical Nutrition & 27 & 0.9 & 6.926 \\
$16^{\text {th }}$ & Current Opinion in Clinical Nutrition and Metabolic & 27 & 0.9 & 4.023 \\
$18^{\text {th }}$ & Care & Nature Reviews Endocrinology & 26 & 0.9 \\
$19^{\text {th }}$ & Journal of Nutrition & 25 & 0.8 & 48.318 \\
$20^{\text {th }}$ & Journal of Nutritional Biochemistry & 24 & 0.8 & 4.518 \\
\hline
\end{tabular}

3 Abbreviation: NA, not available. 
Table 4 (on next page)

Distribution of the journals in Bradford's zones 
1 Table 4. Distribution of the journals in Bradford's zones

\begin{tabular}{ccccc}
\hline $\begin{array}{c}\text { Bradford's } \\
\text { Zones }\end{array}$ & $\begin{array}{c}\text { Number of } \\
\text { Journals }\end{array}$ & \% Journals & Number of articles & $\begin{array}{c}\text { Bradford's } \\
\text { multiplier }\end{array}$ \\
\hline 1 & 6 & 0.6 & 314 & \\
2 & 10 & 1.1 & 312 & 1.67 \\
3 & 15 & 1.6 & 304 & 1.50 \\
4 & 24 & 2.6 & 300 & 1.60 \\
5 & 35 & 3.7 & 302 & 1.46 \\
6 & 53 & 5.6 & 305 & 1.51 \\
7 & 88 & 9.4 & 305 & 1.66 \\
8 & 139 & 14.8 & 304 & 1.58 \\
9 & 265 & 28.2 & 305 & 1.91 \\
10 & 305 & 32.4 & 305 & 1.15 \\
Total number of journals $=940$ & & & \\
Average number of articles in each zone $=305.6$ & & \\
\hline
\end{tabular}
2 